\title{
Optimization of Operational Method to Improve Sustainable Energy Efficiency of Auxiliaries in a CFBC Coal Fired Boiler- Problem Statement and Probable Solution.
}

\author{
Manish R. Moroliya, Vinay Chandra Jha
}

\begin{abstract}
The thermal power station uses some amount of their generated power to be consumed by its auxiliary power requirements. The auxiliary power consumption in the country is around $8-9 \%$. The auxiliary power consumption can be minimize by increasing the load factor, by operational optimization, applying advanced control techniques and energy efficient measures. By decreasing the auxiliary power extra power will be available at grid. Thus, the aim of the audit is to determine the potential areas for minimizing auxiliary power consumption by operational optimization and energy management policy to improve energy efficiency of auxiliaries. This study will give the basic understanding of energy management approach, energy efficiency and energy saving areas so as to achieve maximum plant efficiency resulting fuel saving. Boiler feed pump is one of the equipment in a power plant with the highest auxiliary consumption. The research is specifically targeted at the feed water system and its potential for obtaining considerable energy and cost savings.
\end{abstract}

Keywords: energy audit, boiler feed pump, boiler auxiliary, differential pressure, drum level control, $c f b c$ boiler.

\section{I.INTRODUCTION}

The audit deals with the Energy efficiency achieved through operation of boiler feed pump by means of scoop control in auto mode (DP method) during daily operation of the plant at varying load conditions. The scope of the audit covers the boiler feed pumps and the feed water system in each unit of the AMNEPL power plant. Boiler feed pump is one of the equipments in a power plant with the highest auxiliary consumption. Thus after the study on this audit the results showed that with automated operation of scoop by means of DP method provided considerable savings in auxiliary consumption. The drum with $1.8 \mathrm{~m}$ inner diameter and $2.09 \mathrm{~m}$ outer diameter is hung on front roof by two Urods. Its central elevation is $71.65 \mathrm{~m}$. The size of membrane wall furnace is $16744 \times 20700 \mathrm{~mm}(\mathrm{D} \times \mathrm{W})$, being made up of $\varphi 66.7 \times 8 \mathrm{~mm}$ pipes with a $92 \mathrm{~mm}$ joint interval and being welded together with flat steel. Lay platen SH on the top of high-heat-loaded furnace; the top of nose and the inside of horizontal flue duct are equipped with FSH and FRH in turn.

Revised Manuscript Received on February 05, 2020.

* Correspondence Author

Manish R. Moroliya, Ph.D.Scholar, Department of Mechanical Engineering, Kalinga University, Raipur, C.G, India.

Email: manishmoroliya@gmail.com

Dr. Vinay Chandra Jha, Professor, Department of Mechanical Engineering, Kalinga University, Raipur, C.G, India.

(C) The Authors. Published by Blue Eyes Intelligence Engineering and Sciences Publication (BEIESP). This is an open access article under the CC BY-NC-ND license (http://creativecommons.org/licenses/by-nc-nd/4.0/)
The horizontal fuel duct is formed by winding upper back-wall water wall pipes. Back shaft walls are made up of enclosure wall $\mathrm{SH}$, tail-shaft flue duct is divided into two parts by mid-board, foreside is laid PRH, rearward is laid $\mathrm{PSH}$, and coiled economizer is laid under $\mathrm{PRH}$ and PSH.PSH and PRH are hanged by hanger tube of economizer's mid-header; economizer coiler hangs on economizer mid-header. Water-feeding heated by economizer runs into steam drum first, and then runs into four pieces concentrated sewer pipes after mixing with boiler water, finally leaded to front, rear and two sides' water wall lower header by launch connection tube. Steamwater mixture through water wall and water wall upper header is run into drum by drum-water wall connection tube, which is separated by steam-water separator to fulfill water circulation.

Steel structure erection and covering position should be finished. All high-tension bolts should be tightened and qualified. Boiler proper equipment should be checked as per drawings and regulations, and the exposed defects should be eliminated. All heating surface, pressure parts and accessories of boiler proper (such as buckstays, guiding devices etc.) should be installed as per drawing requirements (including header's inner checking and cleaning, pipes through ball, component alignment and connection working etc.). The pipelines and supports participating in Hydraulic test should be installed. Boiler proper pipelines for emptying, water draining, sampling, nitrogen filling, acid washing, meter controlling, chemical dosing, pollution discharge and de-superheated water have been connected to secondary valve. Pay more attention to heat expansion offset during pipeline erection. All weld craters included in Hydraulic test should be welded, visual inspected, heat treated, NDE ( as stated sampling inspection rate) and qualified. All components welded on heating surface pipes or pressure part should be finished, such as fins, pins, sealing iron parts, preventing wear enclosures, insulation hook nails, valve hole seats and thermal detection parts and expansion joints etc.

\section{II.EQUIPMENTS OF FEEDWATER SYSTEM}

Table 2.1: Technical Specification of Boiler

\begin{tabular}{|c|c|c|}
\hline & Equipment \\
Detail & $\begin{array}{c}\text { Technical } \\
\text { Specification }\end{array}$ & Parameters \\
\hline
\end{tabular}


Optimization of Operational Method to Improve Sustainable Energy Efficiency of Auxiliaries in a CFBC Coal Fired Boiler- Problem Statement and Probable Solution.

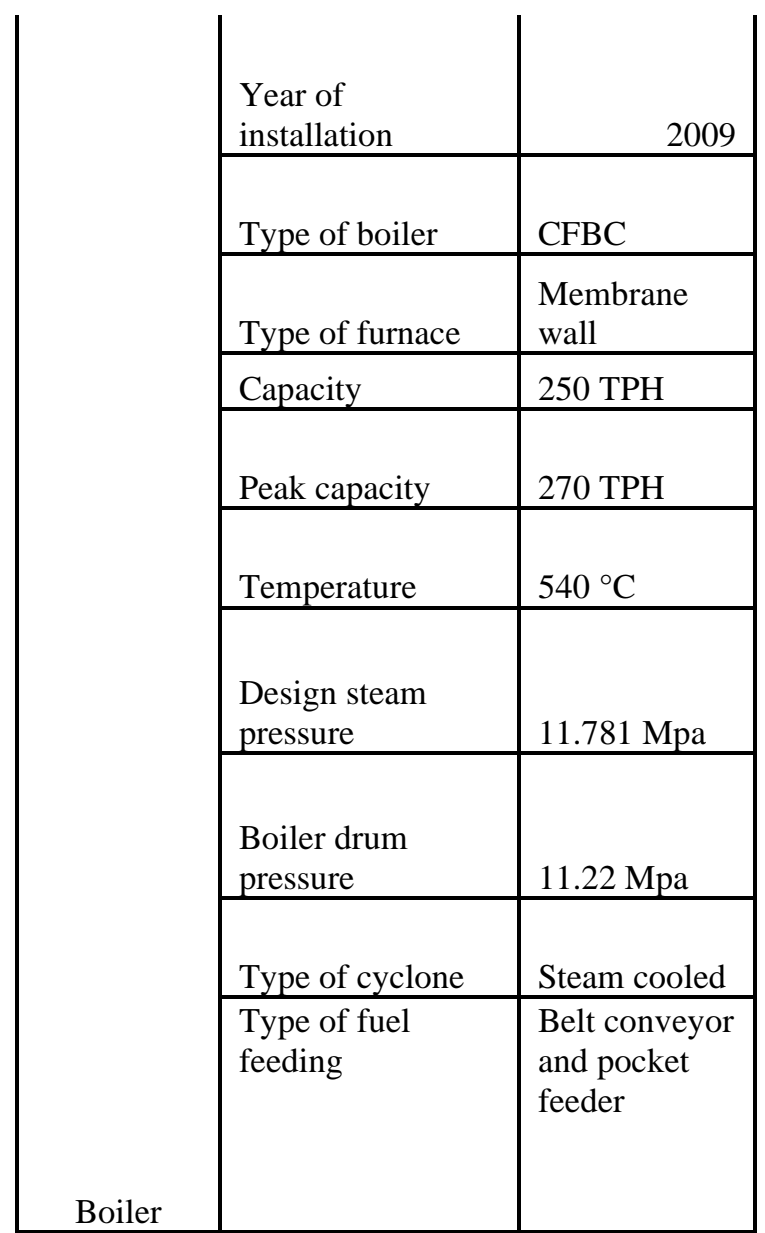

Table 2.2: Technical Specification of Turbine

\begin{tabular}{|c|c|c|}
\hline $\begin{array}{c}\text { Equipment } \\
\text { Detail }\end{array}$ & $\begin{array}{c}\text { Technical } \\
\text { Specification }\end{array}$ & Parameters \\
\hline & $\begin{array}{l}\text { Year of } \\
\text { installation }\end{array}$ & 2009 \\
\hline & Model no. & N61.5-8.83/537 \\
\hline & Type & $\begin{array}{l}\text { High temp.and high } \\
\text { press. non control } \\
\text { extraction } \\
\text { condensing }\end{array}$ \\
\hline & $\begin{array}{l}\text { Maximum } \\
\text { output }\end{array}$ & $61.5 \mathrm{MW}$ \\
\hline & $\begin{array}{l}\text { Main steam } \\
\text { pressure }\end{array}$ & $8.83 \mathrm{Mpa}$ \\
\hline & $\begin{array}{l}\text { Main steam } \\
\text { temp. }\end{array}$ & $537{ }^{\circ} \mathrm{C}$ \\
\hline & $\begin{array}{l}\text { Main steam } \\
\text { flow }\end{array}$ & $238 \mathrm{TPH}$ \\
\hline \multirow[b]{2}{*}{ Turbine } & Rated speed & 3000 RPM \\
\hline & Flow path series & $\begin{array}{l}21 \text { ( } 1 \text { governing } \\
\text { stage }+20 \text { pressures } \\
\text { stage ) }\end{array}$ \\
\hline
\end{tabular}

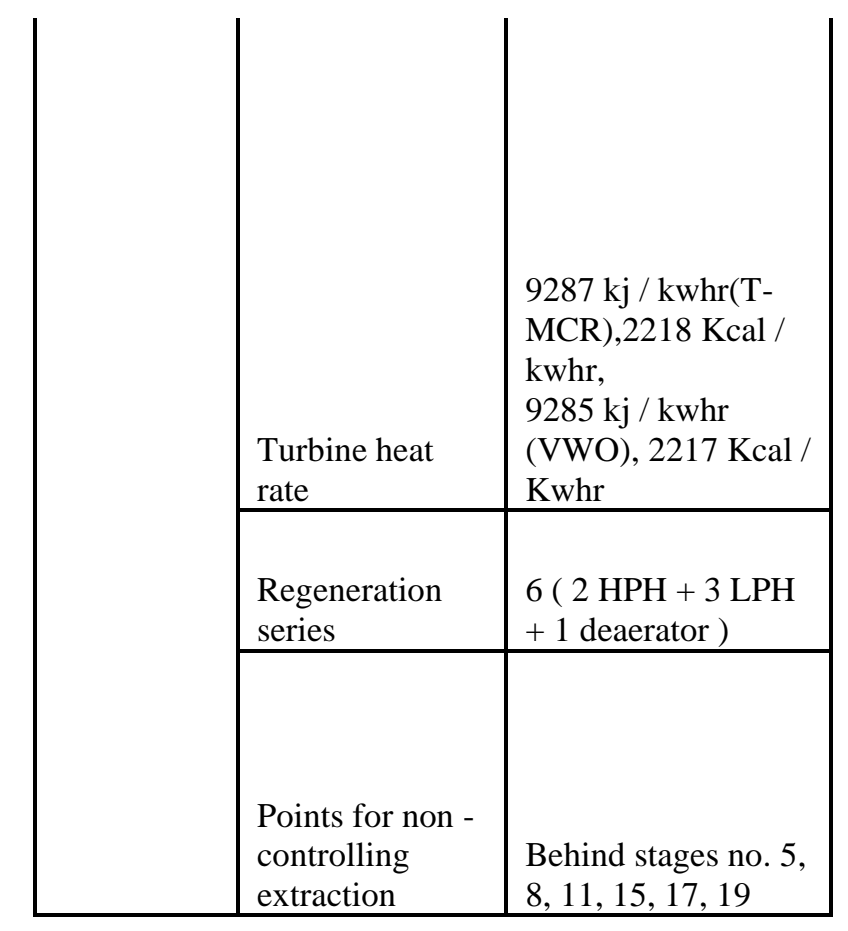

Table 2.3: Technical Specification of Feed Pump Motor

\begin{tabular}{|c|c|c|}
\hline $\begin{array}{c}\text { Equipment } \\
\text { Detail }\end{array}$ & $\begin{array}{c}\text { Technical } \\
\text { Specification }\end{array}$ & Parameters \\
\hline \multirow{10}{*}{$\begin{array}{l}\text { Boiler Feed } \\
\text { Pump Motor }\end{array}$} & Type & Squirrel cage motor \\
\hline & Rated voltage & $6600 v$ \\
\hline & Frequency & $50 \mathrm{hz}$. \\
\hline & Connection & Star \\
\hline & Phase & 3 \\
\hline & $\overline{\text { Speed }}$ & $2985 \mathrm{rpm}$ \\
\hline & Power factor & 0.88 \\
\hline & Current & 166 amps \\
\hline & Efficiency & $96.10 \%$ \\
\hline & $\begin{array}{l}\text { Rated power } \\
\text { output }\end{array}$ & $1600 \mathrm{kw}$ \\
\hline
\end{tabular}

Published By: 


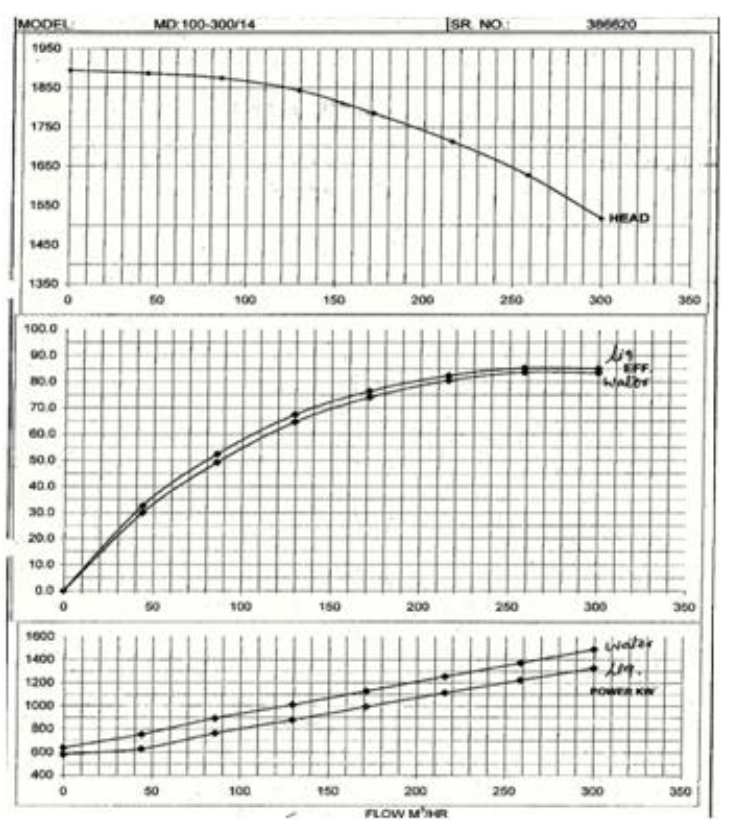

Fig 2.1: Pump Characteristic Curves of Feed Water System

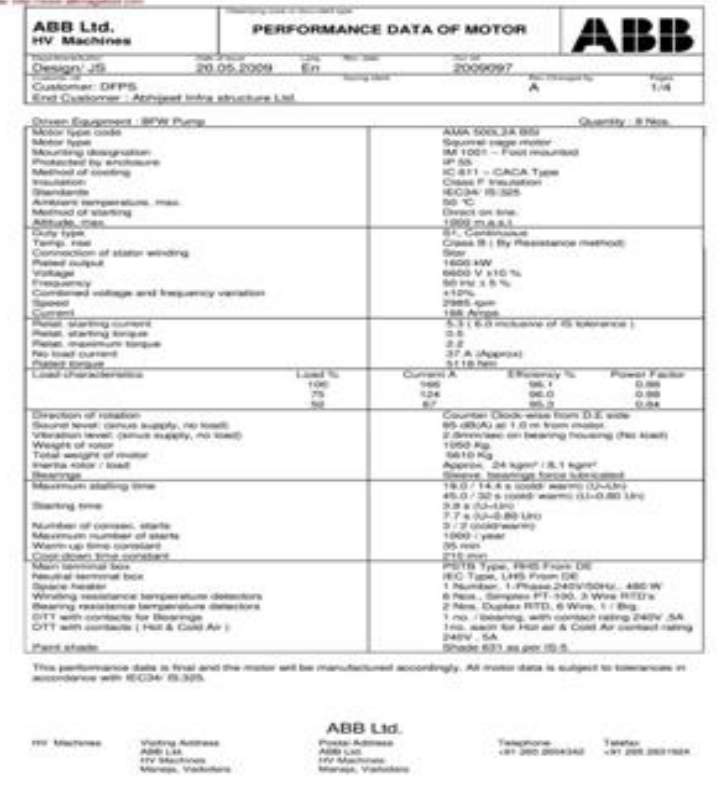

Fig 2.2: Boiler Feed Pump Motor Data Sheet

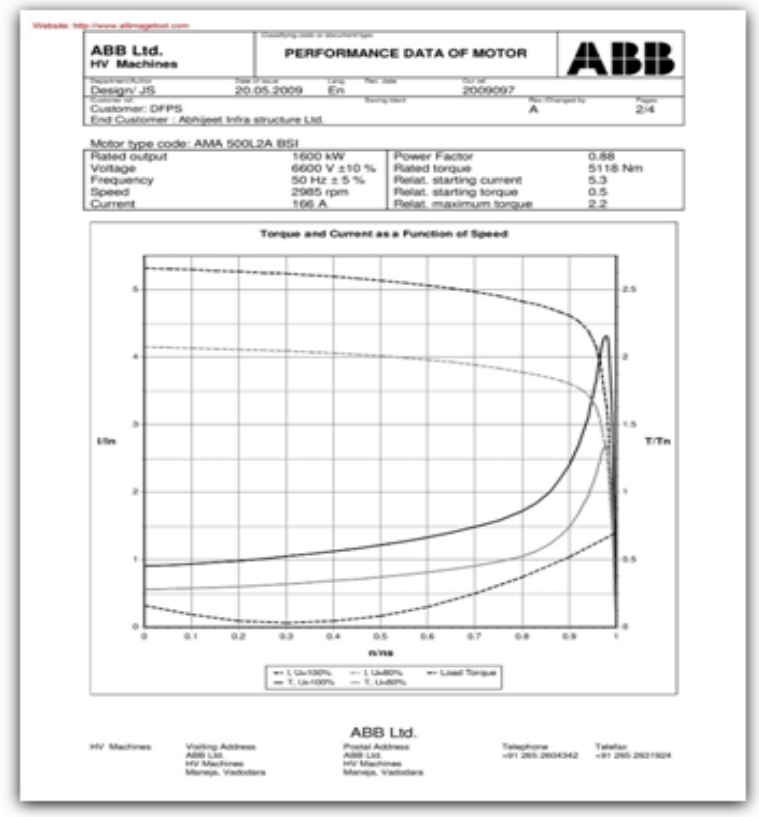

Retrieval Number: C6099029320/2020@BEIESP DOI: 10.35940/ijeat.C6099.029320
Fig 2.3: Performance Data of Motor

(Current and Torque as a Function of Speed)

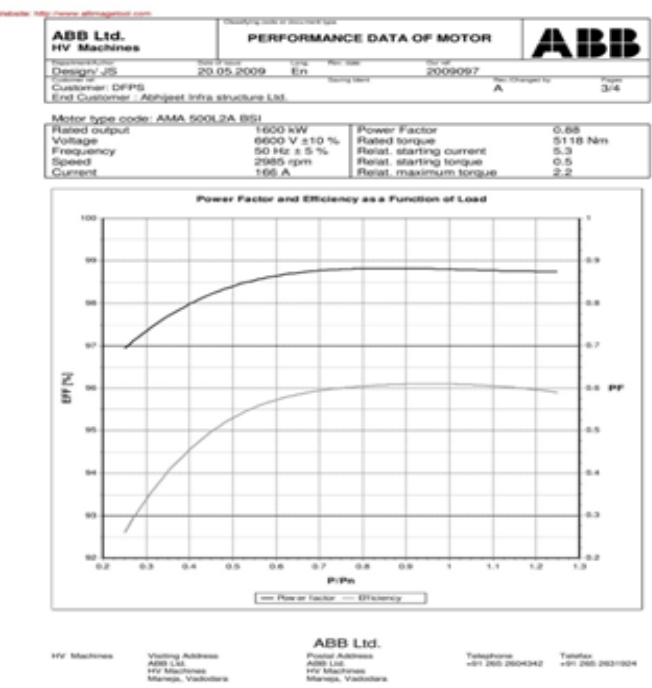

Fig 2.4: Performance Data of Motor

(Power Factor and Efficiency as a Function of Load)

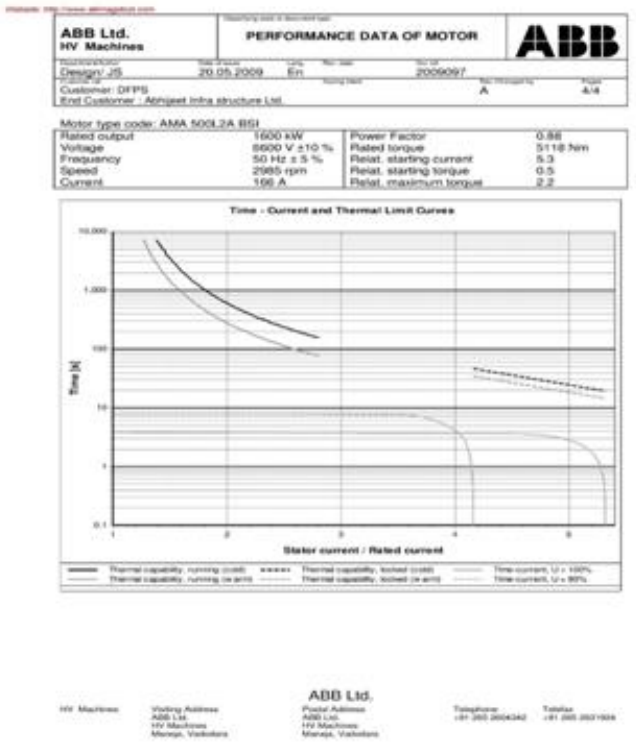

Fig 2.5: Performance Data of Motor

(Time - Current and Thermal Limit Curves)

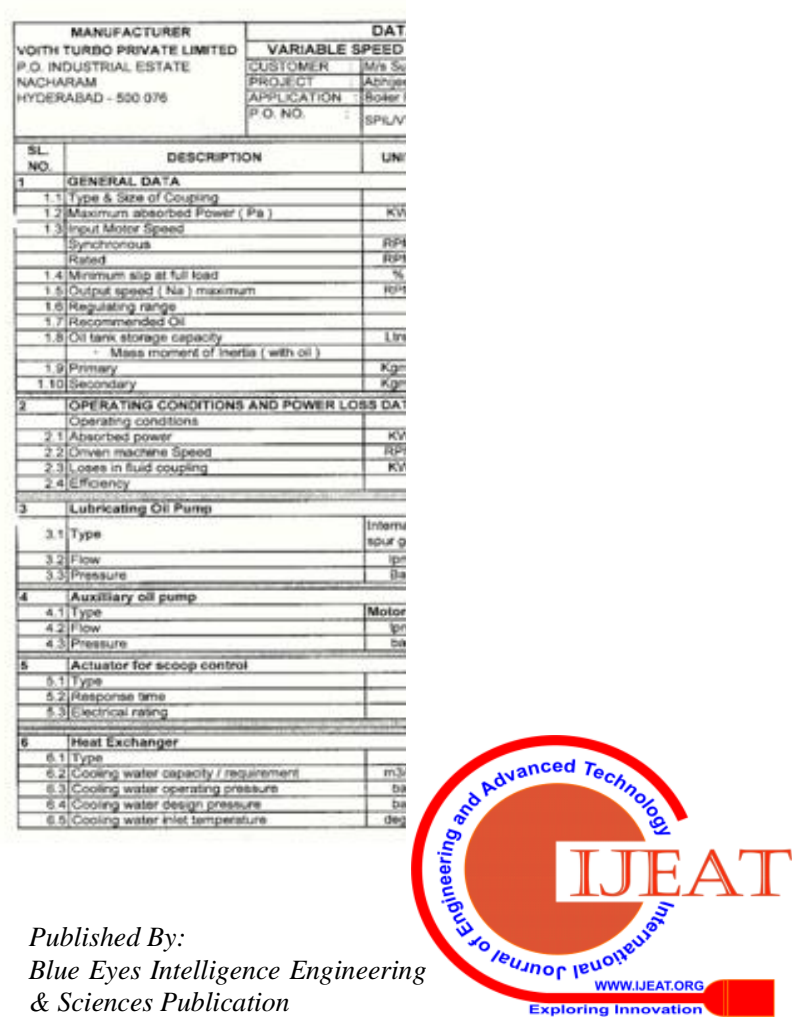




\section{Optimization of Operational Method to Improve Sustainable Energy Efficiency of Auxiliaries in a CFBC Coal Fired Boiler- Problem Statement and Probable Solution.}

\section{Fig 2.6: Variable Speed Hydraulic Coupling Datasheet}

\section{Boiler Drum}

Water wall lower header, enclosure wall lower header and displacement indicator of steam drum should be prepared completely. The erection position should be correct. Indication hand should be firm and adjusted it at zero. Pre-welding parts have been installed on other headers, with which expansion indicators should be equipped. The equipment, pressure weld seams of pipelines and other parts in the range of hydraulic test shouldn't be heat insulated and painted. All measuring gauge that will be used in hydraulic test should be prepared completely and have qualification certificate in the period of validity. Accuracy and measuring range should accord with regulation. The pathway, stair, platform, handrail, temporary scaffold, communication equipment and lighting used in hydraulic test should be installed. Ground and road should be cleaned, unblocked and have no sundries and seeper. Safety valve has been installed and the specific valve core for hydrotest should be installed as per manual. The conduits of PRH inlet, FRH outlet and FSH outlet should be installed. Blocking valves' pressure grade should meet the requirement of hydraulic test.

The water source should use qualified desalted water from chemical water workshop, in which chloride content can't be more than 25ppm. For some proper ammonia liquor and hydrazine have been added into desalted water for hydraulic test and avoiding polluting environment when draining. Temporary draining pipelines should be separately met on inlet header water draining pipe of $\mathrm{PRH}$, inlet header water draining pipe of $\mathrm{PSH}$, lower header water draining pipe of enclosure wall, inlet header draining pipe of economizer and inlet general valve of nearby furnace heating location header, and then the temporary draining pipelines should be concentrated on the main draining pipeline of $\varphi 168 \times 5$,finally the desalted water should be drained to acid and alkali neutralization pond.

\section{Drum Internal Equipments}

When emptying pipes can drain water uniformly for a long time without air bubble, the system has been filled with water. Shut off Emptying pipes valves in the order of effluent water. When the boiler is about to be filled with water, recycle valve of desalted water pump should be opened up slightly. When outlet pressure of condensation water transfer pump should be in the range of $1.1 \sim 1.3 \mathrm{Mpa}$. Shut off outlet valve of condensation water transfer pump after the boiler is filled with water. Then open up \#8 temporary valve and the draining valves of water cooling system, super-heater system and re-heater system. And open up all emptying valves in the inversed order of shutting off emptying valves to drain all of water in furnace for meeting the purpose of flushing heating surface equipment.

Before filling water, the test on site should be conducted as per test table, and the water can be filled after correlated conditions are met positive and signed by every representative. Before filling water, enough desalted water should have been prepared first. Shut off \#1 and \#8 temporary valves when filling water. Pump will be started up by formal condensation water transfer pump (the flow is $160 \mathrm{~m} 3 / \mathrm{h}$, delivery lift is $125 \mathrm{~m}$ ). Then open up water-feeding operation valve, draining valve of $\mathrm{PRH}$ inlet header, \#4 temporary valve, draining valve of FRH outlet header, steam side of double color water gauge, waterside of primary and secondary valves and various emptying valves. Then shut off various left valves. Finally start up condensation water transfer pump and fill water into boiler. During filling water, drum wall temperature difference should be $\leq 50^{\circ} \mathrm{C}$, the temperature difference between filling water temperature and drum wall temperature should be $\leq 28^{\circ} \mathrm{C}$.

Slightly open the outlet valve of condensation water transfer pump and recycle valve. Startup condensation water transfer pump and control its outlet pressure in the range of $1.0 \sim 1.3 \mathrm{Mpa}$ by adjusting the jaw opening of recycle valve. Open up \#8 temporary valve and \#2, \#3 temporary valves of booster pump outlet. Open up the primary valve and secondary valve of a periodic blowdown pipe connection with booster pipe. Open up draining valves of right side FRH and right side FSH outlet headers (for connection primary steam system with secondary steam system). Open up primary valve and secondary valve of double color water gauge steam side and waterside, and shut off \#4 and \#9 temporary valves and every system left valves. Finally start up two sets booster pumps for boosting to furnace. The boosting speed should be controlled within $0.294 \mathrm{Mpa} / \mathrm{min}$.

\section{Problem Identification- Existing System}

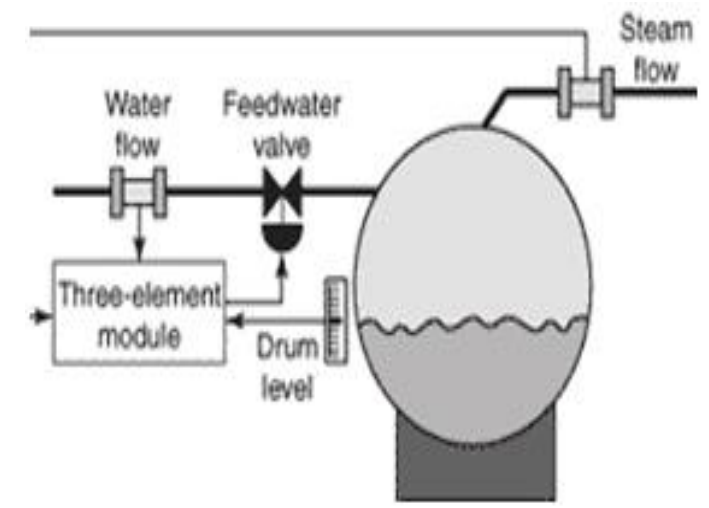

Fig 5.1 Existing Feed Water System

The feed water system consists of the Boiler feed pump, Feed regulation station, Deaerator, high pressure heaters, Economiser. In all four units for maintaining drum level three element control was used where the feed control station was kept in 3 element mode. In this process BFP discharge pressure was being maintained in manual mode by varying scoop position manually. The differential pressure across FRS is maintained at a very higher side i.e. in the range of $25-30 \mathrm{Kg} / \mathrm{cm} 2$. For efficient maintaining of drum level only a DP of $8-10 \mathrm{Kg} / \mathrm{cm} 2$ is sufficient, the rest excess is compensated by throttling of control valve and hence as the DP across FRS is increased unnecessary power is consumed at BFP end.

\section{Probable Solution- Proposed System}




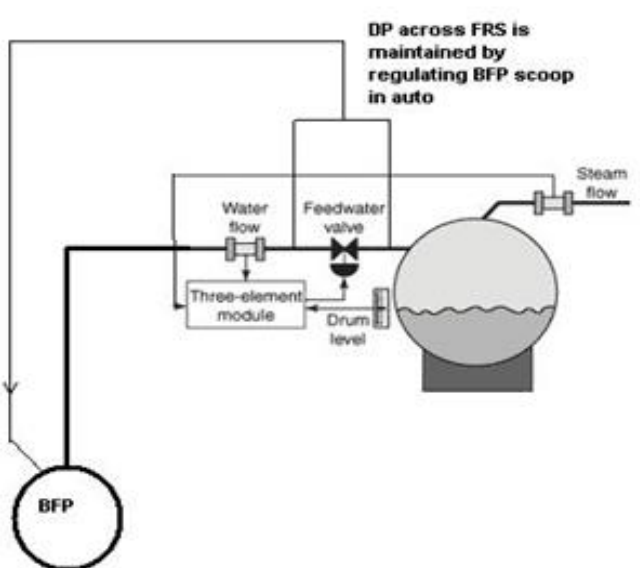

Fig 6.1 Proposed Feed Water System

In the new control philosophy of BFP scoop was put in auto mode which would maintain the Differential pressure across the FRS as per the set point while FRS control valve would maintain the drum level as per 3 element commands to maintain the desired drum level (50\%). No additional investment or material is required as all provisions are inherent and provided in the existing system. It is also recommended to lock the control valves of the FRS station to operate between $0 \%$ (min) - 75\% (max) open condition to ensure that the sensitivity of the Control valves is preserved.

\section{III.RESEARCH METHODOLOGY}

1. Review of literature and detail study of related journals

2. Study of water feed system of Boiler in Thermal power plant.

3. Study of various equipments used in Boiler water feed system

4. Data Collection:

a) System \& Equipments specifications.

b) System \& Equipments Layout diagrams.

c) G.A Drawings of the Equipments.

d) P\&I Drawings of the Systems.

5. To find out scope of Energy conservation \& Efficiency improvement areas.

6. Energy Audit of Existing System.

7. Baseline energy use and Cost of Audited system..

8. Energy conservation recommendations.

9. Energy Audit of Proposed System.

10. Analysis and Calculations:

a) Calculations for Existing system.

b) Calculations for Proposed system.

c) Comparison of Existing system and proposed system.

d) Calculations for Energy savings.

11. Cost benefits and Simple Payback period.

12. Result and Conclusion.

\section{Advantages}

1. It is very robust control and can be used during fluctuating load conditions without any major variation in drum level.

2. With decreased DP across FRS life of control valve also increases.

3. Life of a bearing increases as compare to the existing system.

4. No extra cost is required to implement the system.

\section{IV.CONCLUSION}

The 3 element method consumes more auxiliary power for varying load conditions as the pressure difference is very high. So by adopting new drum control philosophy that require only 8 to $10 \mathrm{~kg} / \mathrm{cm} 2$ differential pressure across feed regulation system (FRS) and scoop in automatic mode provides less human interference. Total auxiliary consumption can be reduced. No extra cost is required to implement the system. Human interference is neglected due to automation.

\section{REFERENCES}

1. T. Rajkumar, V.M. Ramma Priya and K. Gobi, "Boiler Drum Leve Control by Using Wide Open Control with Three Element Control System." International journal of research in management and technology, Volume: 2 (Apr-2013) ISSN: 2320-0073, pp. 85-96.

2. Ms. A.Karthikeyani, G.Nivedha,D.Pavithra and S.Poorani "Boiler Drum Level Control In Full Load Control Valve by using Wide Open Mode by Three Element Method" International Journal of Advanced Science and Engineering Research, Volume: 3, Issue: 1, 2018, ISSN: 2455-9288.

3. Santosh M. Mestry, "Technical paper on major energy saving potential in thermal power plant \& effective implementation of EC Act 2001 in Power Sector." (Issue\#28) Reliance Energy Limited, Dahanu Thane.

4. Manish R. Moroliya, Bhojraj N.Kale and Ashish Mathew Pullenkunnel "Energy Conservation of Boiler Feed Pump by Differential Pressure Autoscoop Control Method" International Journal of Current Engineering and Technology, Vol. 05, No. 3 (June 2015) E-ISSN 2277-4106, P-ISSN 2347-5161

5. G.R. Mahesh, G. Srinivasa Rao, M.V. Giridhar, "Energy Audit of Boiler Feed Pump System and Air Compressor in a Thermal Power Plant." International journal of engineering research and technology, Volume: 2, (Oct-2013) ISSN: 2278-0181, pp. 3316-3322.

6. M. Iacob, G.-D. Andreescu, Drum-boiler control system employing shrink and swell effect remission in thermal power plants, Proc. 2011 3rd International Congress on Ultra-Modern Telecommunications and Control Systems and Workshops (ICUMT), Budapest, Hungary, ISSN: 2157-0221, ISBN: 978-14577- 0682-0, pp. 1-8, Oct. 2011. ieee

7. J.C. Cone, "Pump Energy Conservation Techniques." E.I. du Pont de Nemours and Company, Engineering Department, Wilmington, Delaware, pp. 83-101.

8. G.F. Gilman and Jerry Gilman, "Boiler Control Systems Engineering" ISA Publication, Volume: 2 (2010).

9. NTPC, "500 MW Unit Operation Manual" Volume: 1

10. Abhijeet MADC Nagpur Energy Pvt. Ltd "Technical Logbook."

11. NPTI, "Power Plant Familiarization" Volume: 1.

12. P. Chattopadhyay, "Boiler Operation Engineering." McGraw Hill Professional Second Edition (2001). 